\title{
Role of Indian Muslim Women in Politics
}

\author{
Dr. Saba Yunus \& Dr. Manorama Gupta
}

\begin{abstract}
Women have a poor $11 \%$ representation in India's Lok Sabha and $10.6 \%$ in the Rajya Sabha, making India 108th among 188 countries covered in the annual analysis on statistics of women members of parliament (MPs) conducted by the Inter-Parliamentary Union (IPU).

According to statistics released periodically by the Election Commission, for the 543 Lok Sabha constituencies, the number of elected women increased from 49 in 1999 to 59 in 2009, with $11 \%$ representation in the lower house. In 2009, the number of elected women over total seats was maximum in Punjab (30.8\%), followed by Madhya Pradesh (20.7\%) and Haryana (20.0\%). Against this, the number of women voters in India has increased from $44.3 \%$ to $45.8 \%$.

The patriarchal hereditary nature of Indian politics requires intervention at many levels and in many forms. A 33\% reservation, which is the minimum mass required, will be one of the most significant changes in helping women attain their right to participate in Indian democracy not just as voters but also as leaders,

Representation of Muslims in Indian politics since independence has been disproportionately low, ranging between $6-8 \%$, as compared to their share in the Indian population which is estimated to be around $14 \%$, but believed to be even higher. It is essential for Muslim women to have their own representative in the Parliament. This is more so because the male members of the Parliament do not think that muslim women have any problem but the truth is quite opposite, there are various issues related to women that needed to be properly raised in the Parliament and only women Parliamentarian of muslim community can do that.
\end{abstract}

The main aim of this paper is to find out the status of Muslim women's participation in India.

Keywords - Women, Politics, India, Empowerment..

\section{INTRODUCTION}

$\mathrm{T}$ HE nature and extent of participation of women in the electoral process is thus important from the point of view of women's development. Apart from being an essential mechanism to represent and promote women's interest, it would also be a good indicator of the extent of women's development by way of level of awareness and expectations. It will make more women visible, promote the role model and self-image of women and politicize them.

Women's Participation in Politics:

Political participation is the mother and politics the child. The former creates, nourishes, develops, regulates and determines politics and hence is of utmost importance both for

Dr. Saba Yunus is an Asst. Professor of Sociology at MMV PG College, Kanpur (India) (e-mail: dr.sabayunus@ gmail.com).

Dr. Manorama Gupta is an Assoc. Professor of Political Science at DAV College, Kanpur (India). the nation and for the individual. The politics of the nation is determined, therefore by the political participation in all its processes and lack of or should we say, less political participation by women is responsible for making them extremely less significant than man though they are about half the population.

It is supporting but true, that while it was the political field during the struggle for independence in which women in large number participated, today we have to acknowledge that the number of women in political or public life have not increased very much either in number or in the calibre of the representation. After the independence when the constituent assembly took its final shape, there were only fourteen women elected from the state legislatures on the nomination of congress party on the advice of Mahatma Gandhi. But each and every one of them played an effective part. In view of this when Constitution was adopted, it was a foregone conclusion that women would be given their rightful place in society and under the laws as equals. This was embodied in the Constitution of Democratic Republic of India.

In the late thirtees prompted by Jawahar Lal Nehru, U.P. became a show case province for women's participation in politics. In free India the Constitution guaranteed liberty and equality to citizens irrespective of religion, gender etc. Hence, legally women are on equal footing with men but practically their participation in active politics is not at par with men's. Hence all the constitutional safeguards, their proportion in Indian Parliament as well as State Legislatures is not very significant. Millions of them still remain away from political participation. The main reason for this can be attributed to lack of education, non-cooperation within family, the unsuitable political atmosphere, absence of women leadership at local level and heavy financial implications for elections. There is a heavy competition from male contenders always for seats in the assembly and the Parliament within every political party. Stress and strain involved in political life, besides family responsibilities, also discourage women to become active politicians. Further, seasoned men politicians very often do not allow women legislators to work independently with honesty and dignity. These observations which are of general nature, are confronting many ambitious and capable women from entering into politics.

\section{A. Muslim women and political participation}

Unlike in the Hindu and Christian communities, where religion does not act as a strict barrier to the advancement of women, the conservative character of the Muslim community, its patriarchal society and its strong desire to maintain its 
religious identity imposes restrictions on its women in the public space. While strictly conservative Islamic societies do not allow their women to venture outside their homes except with the permission of her husband or father, in secular India the Muslim women, especially from the poor, uneducated and socio-economically backward groups are under the influence of the Muslim clergy.

The Qur'an contains verses that appear to support the role of women in politics, such as its mention of the Queen of Sheba, who represented a ruler who consulted with and made important decisions on behalf of her people. Further, the Hadith provides numerous examples of women having public leadership roles. Muhammad's first wife Khadija bint Khuwaylid was his chief adviser as well as his first and foremost supporter. His third wife Aisha Abu Bakr, a wellknown authority in medicine, history, and rhetoric, often accompanied the Prophet to battles, even leading an army at the Battle of the Camel. ${ }^{[1]}$ However, it is also within the context of this battle that a famous hadith is ascribed to Muhammad where he says "Never will succeed such a nation as makes a woman their ruler." However, contemporary scholars have cast doubt on the authenticity of this Hadith, citing the odd timing of the Hadith's first release, its contradiction with the verses of the Quran, and the most likely use of the Hadith for a specific person at the time (Queen of Persia) rather than as a general rule or advice.

Though leadership opportunities for Muslim women are cemented in religious text and continue to expand today, earlier generations had different understandings of women's roles.

Despite modern developments and greater inclusion of Muslim women in political life, there are Muslims in certain countries who maintain that the ideal Muslim woman should confine herself to the role of mother and wife. However, there have been scholars in a variety of religious faiths and cultures that have advocated for the same thing.

However, twentieth century has witnessed an awakening among Muslim women in areas of political thought, literature and knowledge

Muslim women of India are also fighting for similar rights and redressal of similar grievances and injustices. But, to be able to fight effectively, enough Muslim women should be in the Parliament. For, if women of other religions in the Parliament, who definitely understand and appreciate the problems of Muslim women, plead their case, the Muslim community is bound to accuse that they are interfering in the internal matters of the community.

In 1996, the government had drafted a Bill providing 33 per cent reservation of seats for women in the Parliament and legislative assemblies. But, refusing to accommodate women, male politicians have repeatedly stone-walled the Bill.

The main causes of low participation of Muslim women in Election both as voters as well as candidates are:

(i) They are not independent voters,

(ii) a majority of them are illiterate

(iii) majority of them make their choice on the basis of suggestions from male members of the family- husband and sons (iv) they lack information and political awareness

(v) they are not politically conscious

\section{CONCLUSION}

Muslim society of India is highly heterogeneous because of the influence of the caste system, which has led to Indianisation of Islam. Indian Muslims are facing various socio-economic problems born out of their educational backwardness. The latter in Muslim women is additionally due to social and cultural factors and the patriarchal nature of Islam as it is practiced in India. Leave alone higher education, often even primary education is not easily accessible to them. Match fixing within the kinship creates distraction among young girls and they lose interest in education. If at all they are fortunate enough to go to a good school, they are often discouraged from seeking higher education, especially overseas. The more highly qualified a girl is, the less are her chances of finding a suitable husband; often due to misconceptions regarding the 'purity' of highly educated girls and those that have studied abroad. Women are conditioned to such an exploitative situation in their lives and accept the laws passed by religious leaders. The only solution to liberate them from the shackles of ignorance, illiteracy, exploitation is through education.

\section{REFERENCES}

[1] Women in Islam. www.unm.edu. Retrieved 2017-05-29. http://www.answering-christianity.com/karim/part_3_k.pdf

[2] "Response to the lies and distortions of christian missionaries about the position of women in islam"(PDF).

[3] Qur'an

[4] Bhutto, Benazir. "Politics and the Muslim Woman". Oxford Islamic Studies Online. Oxford University Press. Retrieved 2 May 2014.

[5] "Qur'an Translations". Islam Awakened. Retrieved 23 April 2014.

[6] http://mymuslimthoughts.blogspot.ca/2015/02/what-does-it-meanwhen-quran-says-men.html

[7] http://mymuslimthoughts.blogspot.ca/2015/02/what-does-it-meanwhen-quran-says-men_10.html

[8] Guindi, Fadwa El and Adis Duderija. "Gender Construction." In The [Oxford] Encyclopedia of Islam and Women. Oxford Islamic Studies Online. 28-Apr-2014. [1]

[9] Philip Mattar, ed. Val. 2. 2nd ed. New York:Macmillan Reference USA, 2004. p890-895.

[10] Halder, Nomita. 'Female Representation in Parliament: A Case Study from Bangladesh' in New Zealand Journal of Asian Studies, 6, 1 (June 2004):27-63, (http://www.nzasia.org.nz/downloads/NZJASJune04/6_1_3.pdf.)

[11] Lalita Kazmi, Women of Pakistan: Fatima Jinnah, 1893-1967, in Jazba Magazine, (http://www.jazbah.org/fatima.php. Also see, Akbar S. Ahmed, Jinnah, Pakistan and Islamic Identity, p13, Routledge 1997.)

[12] Rai, Shirin. 'Class, Caste and Gender: Women in Parliament in India' in International IDEA, 2002, Women in Parliament, Stockholm (http://www.idea.int/publications/wip/upload/CS_India.pdf) 